\title{
The Apocalypse in Codex Alexandrinus: Exegetical Reasoning and Singular Readings in New Testament Greek Manuscripts
}

\author{
GARRICK V. ALLEN \\ Garrick.allen@dcu.ie \\ Dublin City University, Dublin, Ireland
}

\begin{abstract}
This article explores the ways in which the textual history of the New Testament functions as evidence for its early reception history, and how this layer of reception sheds light on the social realities that stand behind textual transmission. The wording of the book of Revelation in Codex Alexandrinus (A02) serves as an illuminating test case, in that it allows us to focus on singular readings that arose from exegetical reasoning linked to scribal awareness of allusions. I begin by exploring the various social and exegetical motivations that influenced scribes to alter the wording of their Vorlagen. I argue that many singular readings can be explained as efforts to explicate the text's deep structure, emphasizing instances where textual variation creates heightened affiliations with antecedent scriptural traditions ("external harmonization"). Next, I examine the wording of Rev 11:4 and 14:9 in A02. The textual evidence indicates that the scribe of A02 was aware of the lexical details of two distinct traditions (OG/LXX Exod 25-26 and 2 Chr 32:12) and that this copyist altered the wording of Revelation in a way that was indicated by the text's implied connection to these traditions. I conclude by offering some observations about the typology of singular readings and scribal awareness of the textual details of the breadth of the scriptural tradition, as well as some reflections on the lessons that New Testament textual critics can learn from the study of the Hebrew Bible in the late Second Temple period.
\end{abstract}

Textual scholars have long recognized that the wording of their manuscripts contain residues of scribal practices and attitudes. The popular caricature of the scribe as automaton, aiming only at the flawless reproduction of an antegraph, is wholly inappropriate in light of the textual evidence provided by the early Greek manuscript record of the New Testament. Evidence suggests that copyists were also, at times, careful readers who altered the wording of their Vorlagen to convey more 
explicitly a work's meaning (deep structure). ${ }^{1}$ For these reasons, textual history functions as a medium for reception history, and actively so. Recently, scholarly interest in the reception of Revelation within its own textual history, focusing primarily on textual variation that appears to be theologically motivated, has intensified. ${ }^{2}$ One emphasis of this trend is on the role of singular readings ${ }^{3}$ in reception, primarily for their potential to illuminate the theological positions of scribes. ${ }^{4}$ While

${ }^{1}$ See Barbara Aland, "Sind Schreiber früher neutestamentlicher Handschriften Interpreten des Textes?," in Transmission and Reception: New Testament Text-Critical and Exegetical Studies, ed. J. W. Childers and D. C. Parker, TS 4 (Piscataway, NJ: Gorgias, 2007), 114-22; Kim HainesEitzen, "The Social History of Early Christian Scribes," in The Text of the New Testament in Contemporary Research: Essays on the Status Quaestionis, ed. Bart D. Ehrman and Michael W. Holmes, 2nd ed., NTTSD 42 (Leiden: Brill, 2014), 479-95, esp. 489.

${ }^{2}$ The reasons for this interest are twofold: first, the Editio Critica Maior of Revelation is currently in production at the Institut für Septuaginta- und biblische Textforschung at the Kirchliche Hochschule in Wuppertal and, second, the peculiarities of Revelation's manuscript tradition in light of other New Testament works (see $\mathrm{n} .7$ below) make it an ideal test case for measuring scribal reception. See Juan Hernández Jr., Scribal Habits and Theological Influences in the Apocalypse: The Singular Readings of Sinaiticus, Alexandrinus, and Ephraemi, WUNT 2/218 (Tübingen: Mohr Siebeck, 2006); Michael Labahn, "Die Schriftrezeption in den großen Kodizes der Johannesoffenbarung," in Die Johannesoffenbarung: Ihr Text und ihre Auslegung, ed. Michael Labahn and Martin Karrer, ABIG 38 (Leipzig: Evangelische Verlagsanstalt, 2012), 99-130; Martin Karrer, "Der Text der Johannesoffenbarung-Varianten und Theologie," Neot 43 (2009): 373-98; Martin Karrer, Sigfried Kreuzer, and Marcus Sigismund, eds., Von der Septuaginta zum Neuen Testament: Textgeschichtliche Eröterungen, ANTF 43 (Berlin: de Gruyter, 2010), 317-423, http:// dx.doi.org/10.1515/9783110240023.

${ }^{3}$ Singular readings in this study are variants that exist only in a single exemplar and have no versional support. They are usually (but not always) considered to be secondary to the initial text.

${ }^{4}$ See particularly Hernández, Scribal Habits and Theological Influences; and Karrer, "Der Text der Johannesoffenbarung," 373-98. Singular readings are valuable data since it is probable that they were the creation of the scribe. This perspective does not always reflect the complex reality of transmission, but singular readings are more likely to attest scribal agency than readings with greater attestation in the tradition. See E. C. Colwell, "Scribal Habits in Early Papyri: A Study in the Corruption of the Text," in The Bible in Modern Scholarship: Papers Read at the 100th Meeting of the Society of Biblical Literature, December 28-30, 1964, ed. J. Philip Hyatt (Nashville: Abingdon, 1965), 370-89, esp. 372; and Barbara Aland, "The Significance of the Chester Beatty Papyri in Early Church History," in The Earliest Gospels: The Origins and Transmission of the Earliest Christian Gospels; The Contribution of the Chester Beatty Gospel Codex P45, ed. Charles Horton, JSNTSup 258 (London: T\&T Clark, 2003), 110-11. D. C. Parker cautions against attributing all textual change to scribal activity; one must also consider the function of New Testament texts in the earliest strata of Christianity ("Scribal Tendencies and the Mechanics of Book Production," in Textual Variation: Theological and Social Tendencies? Papers from the Fifth Birmingham Colloquium on the Textual Criticism of the New Testament, ed. H. A. G. Houghton and D. C. Parker, TS $3 / 6$ [Piscataway, NJ: Gorgias, 2008], 173-84). I agree that the wording of scriptural texts was fluid in this period due in part to their role in the Christian community; nevertheless, scribes were ultimately responsible for the wording preserved on ancient physical realia. 
singular readings provide useful data for multiple areas of exploration, an underdeveloped area of inquiry is the possibility that particular singular readings were influenced by external scriptural traditions (predominantly the OG/LXX) and/or the scribe's awareness of allusions to these traditions. If certain singular readings represent scribal awareness of the broader scriptural tradition, then the study of these readings, and of textual variation in the New Testament more generally, provides evidence for the reading practices of ancient tradents, a layer of evidence that speaks to the social realities of textual transmission and attitudes toward the scriptural text. ${ }^{5}$ The aim of this article is to examine the possibilities and boundaries of the reception of the OG/LXX in the textual history of the New Testament by examining the text of the book of Revelation in Codex Alexandrinus (A02) as an example. I ask two questions: (1) Do selected singular readings in Apoc. A02 (of which there are eighty-four) suggest the scribe's awareness of antecedent scriptural traditions? (2) If so, how is this awareness manifested in the wording of the manuscript? ${ }^{6}$

I closely examine two singular readings in Apoc. A02 as test cases, emphasizing instances where textual alterations betray an awareness of references to the OG/ LXX embedded within Revelation. ${ }^{7}$ It is likely that the scribe was aware of the text

${ }^{5}$ The exegetical variation of scriptural wording is a well-attested phenomenon in the late Second Temple period (see David Andrew Teeter, Scribal Laws: Exegetical Variation in the Textual Transmission of Biblical Law in the Late Second Temple Period, FAT 92 [Tübingen: Mohr Siebeck, 2014]), especially in copies of works that are designed to facilitate understanding at the expense of exact reproduction of wording, but such variation became a more restricted phenomenon as the centuries progressed. The New Testament facilitates comprehension in more subtle ways, in copies that strive by and large for precise replication of wording. A focused study on the boundaries and hermeneutics of textual variation in the New Testament manuscript tradition is needed; the present article is a first step in this direction. On the text as an avenue to social realities, see Bart D. Ehrman, "The Text as Window: New Testament Manuscripts and the Social History of Early Christianity," in Ehrman and Holmes, Text of the New Testament in Contemporary Research, 479-95.

${ }^{6}$ For more on the diffusion of singular readings in A02, see Hernández, Scribal Habits and Theological Influences, 100 n. 14, 212-15. Additionally, the assumption that scribes are responsible for every reading is, as Ulrich Schmid has argued, faulty or at least difficult to determine ("Conceptualizing 'Scribal' Performances: Reader's Notes," in The Textual History of the Greek New Testament: Changing Views in Contemporary Research, ed. Klaus Wachtel and Michael W. Holmes, TCSt 8 [Atlanta: Society of Biblical Literature, 2011], 49-64). The readings explored in this discussion, however, are attributed to the scribe. The importance of this discussion is not attribution but the fact that these textual changes are the result of someone's cognitive processes.

${ }^{7}$ I selected A02 for this study because of its recognized quality in terms of the text of the Apocalypse, in light of the relatively few extant early manuscripts of the book of Revelation. See James R. Royse, Scribal Habits in Early Greek New Testament Papyri, NTTSD 36 (Leiden: Brill, 2008), 45-46. For a full accounting of the peculiarity and uniqueness of the Greek manuscript traditions of the book of Revelation, see J. Delobel, "Le texte de l'Apocalypse: Problèmes de méthode," in L'Apocalypse johannique et l'apocalyptique dans le Nouveau Testament, ed. J. Lambrecht, BETL 53 (Leuven: Leuven University Press, 1980), 151-56; J. K. Elliott, New Testament Textual Criticism: The Application of Thoroughgoing Principles; Essays on Manuscripts and Textual Variation, NovTSup 137 (Leiden: Brill, 2010), 145-55, http://dx.doi.org/10.1163/ 
of writings in the OG/LXX tradition, and it is surprising that external influences on textual variation have not yet been explored in greater detail-particularly since the Apocalypse is notoriously allusive. ${ }^{8}$ The reuse of scriptural wording in Revelation suggests concrete relationships with antecedent texts, especially to scribes well versed in the wording of antecedent traditions.

The following examples provide numerous platforms for further discussion. First, this analysis identifies an underappreciated external pressure that shaped the textual history of the book of Revelation: allusion to scriptural traditions already embedded in the composition. Second, it provides information about the producer of Apoc. A02, elucidating the scribe's reading and transcribing practices. If we are able to better understand the scribe's performance (the mechanics and social settings of text production), we can more fully comprehend the textual anomalies present in the copy, which leads to a more comprehensive appreciation of the forces that created textual variation in Christian antiquity. ${ }^{9}$

\section{A Typology of Singular Readings}

Singular readings are not always the result of intentional cognitive processes; therefore, care must be taken to avoid the assumption of scribal intention where it

ej.9789004189522.i-664; H. C. Hoskier, Concerning the Text of the Apocalypse: Collations of All Existing Available Greek Documents with the Standard Text of Stephen's Third Edition, together with the Testimony of Versions, Commentaries and Fathers; A Complete Conspectus of All Authorities, 2 vols. (London: Quaritch, 1929); JosefSchmid, Studien zur Geschichte des griechischen ApokalypseTextes, 2 vols. (Munich: Karl Zink, 1955-1956), vol. 2; D. C. Parker, An Introduction to the New Testament Manuscripts and Their Texts (Cambridge: Cambridge University Press, 2008), 227-45; Markus Lembke, "Beobachtungen zu den Handschriften der Apokalypse des Johannes," in Labahn and Karrer, Die Johannesoffenbarung, 19-69.

One hand was responsible for the production of the Apocalypse in A02. F. G. Kenyon argued that the scribe of this work only produced the Apocalypse and no other works present within A02 (The Codex Alexandrinus [Royal MS. 1 D v-viii] in Reduced Photographic Facsimile: New Testament and Clementine Epistles [London: Longmans, 1909], 10). Marcus Sigismund also finds that the paleography of Apoc. A02 is consistent ("Schreiber und Korrektoren in der Johannes-Apokalypse des Codex Alexandrinus," in Karrer, Kreuzer, and Sigismund, Von der Septuaginta zum Neuen Testament, 319-38). Although I examine only two examples closely here, there are numerous other examples of singular readings in A02 that were influenced by the Greek text of the Old Testament. For example, Delobel points to the influence of Jer 15:2 and 50:11 in Rev 13:10 ("Le texte de l'Apocalypse," 162-65).

${ }^{8}$ See Juan Hernández Jr., "Recensional Activity and the Transmission of the Septuagint in John's Apocalypse: Codex Sinaiticus and Other Witnesses," in Labahn and Karrer, Die Johannesoffenbarung, 83, who notes that "Christian scribes throughout this period [fifth century CE] would have been in a position to identify differences between extant copies of the LXX and the Apocalypse's allusions to it."

${ }^{9}$ See a similar sentiment in Elliott, New Testament Textual Criticism, 64. 
does not exist. Five distinct but interrelated underlying motivations/mechanics give rise to particular presentations of singular readings.

First, singular readings may reflect the reading in the initial copy or Urtext. ${ }^{10}$ In this case, the reading was corrupted at an early stage and subsequently transmitted, in one or multiple alternative forms, by the majority of the manuscript tradition. This option is a theoretical possibility, especially for the book of Revelation. The Apocalypse's minimal early attestation in the Greek tradition (in comparison to other New Testament works), as well as the other anomalous features of its transmission, heightens the possibility that a reading from an early witness may be "original." ${ }^{11}$ For readings that are grammatically cohesive and logically coherent, this must remain at least initially an open possibility.

Many singular readings in Apoc. A02 are also transcription errors, or examples of variable orthographic practices or itacisms. ${ }^{12}$ Vowel/diphthong replacement of one or two graphemes (e.g., Rev 2:6a, 7b; 4:6; 5:9; 7:1a; 8:1; 21:20a), consonantal replacement (12:11, 14:18, 22:8b), and omission of graphemes (3:4) occur in Apoc. A02 in modes commensurate with the transmission of other Greek literatures. ${ }^{13}$ Also present are examples of morphological variation (2:14a, 15:6) or the confusion of graphically similar lexemes $(2: 14 \mathrm{~b}, 6: 8 \mathrm{a}, 8: 5,17: 8)$ that result in nonsensical or incohesive texts. ${ }^{14}$ These readings mostly represent in scribendo accidents in copying. Though they can illuminate particular transcription processes or linguistic conventions of a specific locale or time period, they provide little useful data pertinent to reception history or the perception of allusions to external traditions. If they are helpful for the question of reception at all, they may provide evidence for the ways that scribes interacted with the substance of their Vorlage in the process

${ }^{10}$ For a long period, singular readings were considered valuable only insofar as they might accurately reflect the "original" text. See perspectives on the singular readings in A02 in R. H. Charles, A Critical and Exegetical Commentary on the Revelation of St. John, 2 vols., ICC (Edinburgh: T\&T Clark, 1920), 1:clxxi-clxxii; Delobel, "Le texte de l'Apocalypse," 161-66; Bernhard Weiss, Die Johannes-Apokalypse: Textkritische Untersuchungen und Textherstellung, TUGAL 7 (Leipzig: Hinrichs, 1891), 147-48. See also Dirk Jongkind, Scribal Habits of Codex Sinaiticus, TS 5 (Piscataway, NJ: Gorgias, 2007), 131-43. The most recent appraisal of singular readings in A02 and the Urtext is in Hernández, Scribal Habits and Theological Influences, 96-100, $124-25$. He suggests that only three singular readings in this manuscript represent the Urtext (Rev

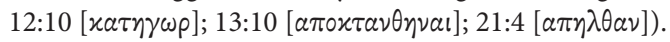

${ }^{11}$ The book of Revelation is preserved in only 307 manuscripts, according to Lembke ("Beobachtungen zu den Handschriften," 21), the vast majority of which derive from the Byzantine period.

${ }^{12}$ This is true for many singular readings in the early New Testament manuscripts more generally. See Peter M. Head, "The Habits of New Testament Copyists: Singular Readings in the Early Fragmentary Papyri of John," Bib 85 (2004): 399-408, esp. 407; Colwell, "Scribal Habits in Early Papyri," 374-77.

${ }^{13}$ See Hernández, Scribal Habits and Theological Influences, 103-4.

${ }^{14}$ See ibid., $105-6$. 
of copying, potentially illuminating the textual features that arrested the attention of copyists.

A singular reading may also reflect a desire to explicate the internal discourse of a work, a type of reading that provides evidence for reception. ${ }^{15} \mathrm{~A}$ clear example of this type of explicative variation, although not properly a singular reading, occurs in Apoc. A02 4:3. ${ }^{16}$ The vast majority of the manuscripts read "and a rainbow [ĩ $1 \zeta]$ around the throne," while the minority reading is "and priests [I€P€IC] around the throne." ${ }^{17}$ The reading in A02 is clearly secondary, as it disrupts the

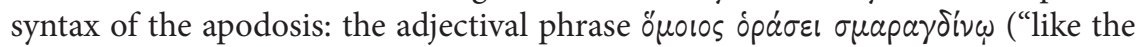
appearance of emerald") supposes a singular antecedent. ${ }^{18}$ There is no obvious external tradition that influenced the wording of this locution. The change was made based on internal concerns; in this case, the ubiquitous cultic imagery associated with the depiction of the heavenly court in Rev 4-5. It is logical to identify the twenty-four elders as heavenly priests who minister before God, since both are

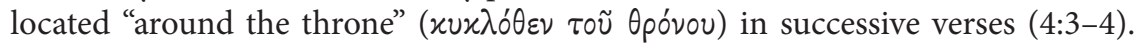
Furthermore, îpıs occurs elsewhere in the New Testament only in Rev 10:1, and only once in the OG/LXX tradition (Exod 30:24) ${ }^{19}$ Its rarity and semantic opacity, perhaps, made it a target for revision to a contextually logical and graphically similar alternative. The effect of this subtle alteration is that the cultic dimensions of the heavenly court are now more pronounced, complete with a heavenly priesthood. ${ }^{20}$ Readings that explicate the internal coherence of a word or locution tend, especially at the lexical level, to heighten an already present profile of images attached to a given passage. These singular readings may also create a greater level of grammatical cohesion. In this example, cohesion is sacrificed for the sake of coherence, but this dialectic varies in this type of reading. ${ }^{21}$

An additional category of singular readings includes those that are assimilated to social compunctions or theological attitudes operative at the time of transcription. Hernández suggests that certain singular readings in Apoc. A02 emphasize,

${ }^{15}$ E.g., Rev 1:10a, 2:7a, 6:1, 14:1 in A02. This is often called "harmonization to the immediate context." See Peter M. Head, "Observations on Early Papyri of the Synoptic Gospels, especially on Scribal Habits," Bib 71 (1990): 240-47; Colwell, "Scribal Habits in Early Papyri," 377-78.

${ }^{16}$ See also $\aleph 2329$ and the numerous itacistic readings noted by Hoskier, Concerning the Text, 2:122-23.

${ }^{17}$ The reading in $\boldsymbol{\aleph}$ was later corrected to "rainbows" (IP€IC).

${ }^{18}$ So Karrer, "Der Text der Johannesoffenbarung," 384-86.

${ }^{19} \boldsymbol{N}$ reads $\theta p ı \xi$ in Rev 10:1, a singular reading. îpıs in the context of Exod 30:24 refers to botanicals. See LSJ, s.v. İpıs; and John William Wevers, Notes on the Greek Text of Exodus, SCS 30 (Atlanta: Scholars Press, 1990), 499.

${ }^{20}$ Karrer, "Der Text der Johannesoffenbarung," 388.

${ }^{21}$ See, for example, the small-scale addition of material in Apoc. A02 6:6 and 9:11 that creates greater grammatical cohesion. In 9:11, the addition of $\tau \dot{o} v a$ ä $p$ ov $\tau \alpha$ creates both a heightened level of coherence and cohesion. In addition, in Apoc. A02 1:1 and 21:20b, the case of nouns is altered to create greater grammatical cohesion. 
albeit subtly, christological aspects of the composition. ${ }^{22}$ These alterations are not the result of textual harmonization but reflect the ideological attitude or milieu of the text producer. ${ }^{23}$

Finally, singular readings can reflect the result of scribal awareness of external scriptural traditions. ${ }^{24}$ This type of reading is the result of a conscious mechanic that draws the text into closer alliance with specific source traditions, based on the scribe's perceived boundaries of the scriptural tradition and knowledge of its wording. These readings differ from internal harmonization in that correlation to external traditions occasionally results in readings that are "nonsense in context" or awkward turns of phrase that may confuse internal discourse, though they often retain a high level of grammatical cohesion. In these cases deference is given to external traditions, sometimes over and above internal coherence and/or cohesion, based on perceived overlap (of either wording or content) between a source tradition and a locution in Revelation. While both internal and external influences can result in singular readings (identical operations), the underlying motivations behind these changes fundamentally differ. This creates a typology of singular readings. ${ }^{25}$

\begin{tabular}{|l|l|}
\hline \multicolumn{2}{|c|}{ A Typology of Singular Readings } \\
\hline Type 1 & $\begin{array}{l}\text { A reading present in the "initial text" that is now transmitted in a single } \\
\text { manuscript. }\end{array}$ \\
\hline Type 2 & $\begin{array}{l}\text { A reading that results from a number of different transcription errors or } \\
\text { diachronic spelling conventions, often yielding a nonsense readings. }\end{array}$ \\
\hline Type 3 & $\begin{array}{l}\text { Conscious changes to wording that create greater grammatical cohesion and/ } \\
\text { or discourse coherence based on internal criteria, often smoothing rutted } \\
\text { texture. }\end{array}$ \\
\hline Type 4 & $\begin{array}{l}\text { Conscious changes to wording based on external social, doctrinal, or } \\
\text { theological norms. }\end{array}$ \\
\hline Type 5 & $\begin{array}{l}\text { Conscious changes to wording influenced by external scriptural traditions or } \\
\text { the awareness of allusions embedded in the work being transcribed. }\end{array}$ \\
\hline
\end{tabular}

${ }^{22}$ E.g., A02 1:17; 2:8, 22. See Hernández, Scribal Habits and Theological Influences, 126-31.

${ }^{23}$ See the classic work of Bart D. Ehrman, The Orthodox Corruption of Scripture: The Effect of Early Christian Controversies on the Text of the New Testament (Oxford: Oxford University Press, 1993), who interacts with Revelation only in a cursory manner.

${ }^{24}$ This phenomenon is prevalent in the Gospels. The wording of Synoptic parallels is often "harmonized to remote parallels." See Head, "Observations on Early Papyri," 246; Colwell, "Scribal Habits in Early Papyri," 377; Elliott, New Testament Textual Criticism, 53-64, esp. 54.

${ }^{25}$ Tommy Wasserman also presents a typology of singular readings, focusing on different forms of theological clarification ("Theological Creativity and Scribal Solutions in Jude," in Houghton and Parker, Textual Variation, 75-83). 
These types of readings reflect, on the one hand, text historical or transcriptional accidents (types 1-2), and, on the other, varying forms of explication or clarification (types 3-5). The final three categories in this typology reveal exegetical or interpretive processes that give rise to textual change, shedding light on the reception of the work by scribal tradents. The remainder of the article focuses on type 5 readings in $\mathrm{A} 02$.

\section{SCRibal Awareness of EMBEDDED SCRIPTURAL REFERENCES}

A scribe's awareness of references to Scripture embedded in New Testament works is determined by a number of features. ${ }^{26}$ Physical characteristics of manuscripts and paratextual features-indentation, the use of diplés (marginal dots) and other marginalia, paragraph division, and so on - can denote sensitivity to external traditions. ${ }^{27}$ These physical and paratextual markers are nonexistent in the test cases examined below (Apoc. A02 11:4 and 14:9), but they remain an important aspect of textual transmission since most facilitating features of the New Testament manuscript tradition take the form of paratexts (e.g., explicit commentary traditions or glosses). ${ }^{28}$ In addition to physical characteristics, unique textual readings aid in measuring scribal awareness of an OG/LXX work. ${ }^{29}$ The presence of a lexeme located in only a single manuscript that alters the traditional reading(s) toward the wording of a particular OG/LXX tradition suggests that the scribe identified an

${ }^{26}$ See Ronald Henry van der Bergh, “The Textual Tradition of Explicit Quotations in Codex Bezae Cantabrigiensis of the Acts of the Apostles" (PhD. diss., University of Pretoria, 2013), 3-5.

${ }^{27}$ On the use of diplés specifically, see Ulrich Schmid, "Die Diplé: Einführung," in Karrer, Kreuzer, and Sigismund, Von der Septuaginta zum Neuen Testament, 77-81. See also Johannes de Vries and Martin Karrer, "Early Christian Quotations and the Textual History of the Septuagint: A Summary of the Wuppertal Research Project and Introduction to the Volume," in Textual History and the Reception of Scripture in Early Christianity / Textgeschichte und Schriftrezeption im frühen Christentum, ed. Johannes de Vries and Martin Karrer, SCS 60 (Atlanta: Society of Biblical Literature, 2013), 9; and, in the same volume, Alexander Stokowski, "Diplé-Auszeichnung im Codex Vaticanus Graecus 1209 (B): Liste nebst einigen Beobachtungen," 93-113.

${ }^{28}$ Marcus Sigismund confirms that there are no diplés in the Apocalypse of A02 ("Formen und Verwendung der Diplé im Codex Alexandrinus," in Karrer, Kreuzer, and Sigismund, Von der Septuaginta zum Neuen Testament, 132). The Greek tradition of Revelation from the sixth century onward is dominated by multiple commentary traditions, especially the commentary associated with Andrew of Caesarea. See Eugenia Scarvelis Constantinou, Guiding to a Blessed End: Andrew of Caesarea and His Apocalypse Commentary in the Ancient Church (Washington, DC: Catholic University of America Press, 2013).

${ }^{29}$ Van der Bergh, commenting on the text of Acts in Codex Bezae, notes that "OT awareness can also be shown by a variant reading peculiar to a NT manuscript or group of manuscripts" (“Textual Tradition of Explicit Quotations," 3). 
embedded reference to traditional material. It is this lexical criterion that anchors the following investigation.

\section{Revelation 11:4}

The first example of a singular reading that is influenced by scribal awareness of the wording of an external text is preserved in Apoc. A02 11:4.

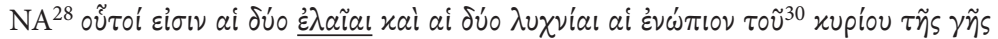
$\dot{\varepsilon} \sigma \tau \tilde{\omega} \tau \varepsilon \varsigma$

These are the two olive trees and the two lampstands which are standing before the Lord of the earth.

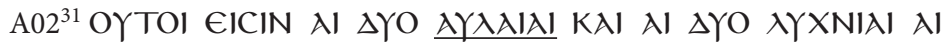 ENWПIO $K \bar{Y}$ THC ГHC ECTWTEC}

These are the two curtains and the two lampstands which are standing before Kyrios of the earth.

This lexical substitution of $\lambda Y \lambda \lambda I \lambda I$ for $\dot{\varepsilon} \lambda \alpha \tilde{i} \alpha$ in Apoc. A02 is exceptional; and, as Hernández notes, "it is difficult to discern what could have prompted the change." ${ }^{32}$ The word aủ $\alpha$ ía is not present in the lexical stock of the New Testament, and within the OG/LXX tradition this lexeme functions as a terminus technicus, referring almost exclusively to the curtains of the wilderness tabernacle (see Exod $25-26 ; 37) .^{33}$

Furthermore, Rev 11:4 preserves a clear scriptural reference to Zech 4:14. ${ }^{34}$ The verbal connection to this text is obscured by the lexical choice of the singular reading in A02. While this veiling of Zechariah material may suggest that the scribe did not perceive this allusion, it is equally probable that the scribe wished to weight

${ }^{30}$ This article is not witnessed in A02 04610061841.

${ }^{31}$ Column 1 leaf 131 b lines 29-31.

${ }^{32}$ Hernández, Scribal Habits and Theological Influences, 119 n. 110.

${ }^{33}$ The word occurs twenty times in the OG/LXX (Exod 26:2-6; 37:1 [36:8], 2 [36:9], 10 [38:12], 13 [38:15], 14 [38:16]; 40:19). It also occurs in OG Isa 54:2 in a text that recalls tabernacle language embedded in Exod 26; 37. Judith 14:14 employs this lexeme to describe the entrance of the tent of Holofernes following his beheading. The only instance in which the text preserved in Exodus of A02 differs from OG Exodus in reference to the lexeme av $\lambda$ al $\alpha$ occurs in Exod 37:14

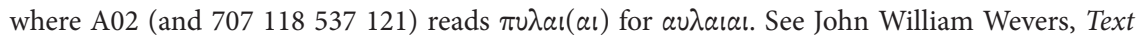
History of the Greek Exodus, AAWG 192 (Göttingen: Vandenhoeck \& Ruprecht, 1992), 93-103. The term retained its technical character in other Jewish and early Christian Greek literature. See, e.g., Philo, Mos. 2.85.1; 2.86.2; Justin, Dial. 13.8.5; Eusebius, Dem. Ev. 3.2.73.5; Cyril of Alexandria, Commentarius in xii Propheta Minores 2.304, among others.

${ }^{34}$ See Garrick V. Allen, "Textual Pluriformity and Allusion in the Book of Revelation: The Text of Zechariah 4 in the Apocalypse," ZNW 106 (2015): 136-45, http://dx.doi.org/10.1515/ znw-2015-0008. 
this locution with the import of an additional antecedent tradition: Exod 25-26. The cultic imagery of Zech 4 (gold lampstands, lamps, thrones, bowls, oil) corresponds closely to language in the tabernacle construction narrative, and the reading in A02 preserves connections to both of these related traditions. ${ }^{35}$ There is a distinct and traceable traditional line from Exodus to Zechariah to Rev 11:4, of which the scribe demonstrates some awareness. ${ }^{36}$

Nonetheless, in light of the use of aủ $\lambda$ aí $\alpha$ as a technical term to refer to a component of the wilderness tabernacle, the identification of the two witnesses as "curtains" is peculiar. Martin Karrer has observed that this singular reading weights the pericope with another example of cultic imagery, but it is not clear how this alteration contributes any literary, cohesive, or ideological value to the narrative of $\operatorname{Rev} 11 .^{37}$

\section{Type of Singular Reading}

Where in the typology does this singular reading belong? The graphic and

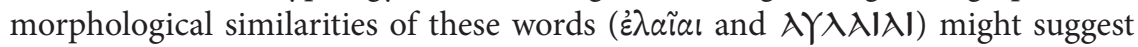
that the reading is the result of graphic/aural confusion - that is, a transcriptional mistake (type 2). This type of interchange is not uncommon. Nonetheless, it is difficult to envision a scenario in which $\lambda Y$ could have been confused with epsilon in the scribe's Vorlage based on graphic similarity. Phonological similarity might

${ }^{35}$ Others have noted that the language of Rev 11:1-5 relates both to Zechariah and to Exodus. See Ferrell Jenkins, The Old Testament in the Book of Revelation (Grand Rapids: Baker, 1972), 80-83; G. K. Beale, The Book of Revelation: A Commentary on the Greek Text, NIGTC (Grand Rapids: Eerdmans, 1999), 576; Jan Dochhorn, "Beliar als Endtyrann in der Ascensio Isaiae," in Die Johannesapokalypse: Kontexte - Konzepte - Rezeption, ed. Jörg Frey, James A. Kelhoffer, and Franz Tóth, WUNT 287 (Tübingen: Mohr Siebeck, 2012), 308; James C. VanderKam, From Revelation to Canon: Studies in the Hebrew Bible and Second Temple Literature, JSJSup 62 (Leiden: Brill, 2000), 168-70, 173-76.

${ }^{36}$ The scribe's forging of connections between like traditions is an ancient mechanic, which finds evocative parallels in legal exegesis in numerous documents from the Second Temple period. See Teeter, Scribal Laws, 175-204. For example, 11QT XLVIII, 7-11 integrates material from Lev 19:28 within a locution from Deut 14:1-2 based on their lexical and thematic overlap (see Moshe J. Bernstein and Shlomo A. Koyfman, "The Interpretation of Biblical Law in the Dead Sea Scrolls: Forms and Methods," in Biblical Interpretation at Qumran, ed. Matthias Henze, SDSSRL [Grand Rapids: Eerdmans, 2005], 67-68). The acceptable level of textual alteration is greater in the Temple Scroll and other similar documents, and its presentation much more overt, but the underlying motivation and mechanic is identical to the singular reading in Apoc. A02 11:4: like texts, sharing lexical and thematic features, are combined to form new, multilayered reservoirs of tradition.

${ }^{37}$ Karrer, "Der Text der Johannesoffenbarung," 383. See also the emphasis on liturgical language in the Apocalypse as a whole in Gottfried Schimanowski, Die himmlische Liturgie in der Apokalypse des Johannes: Die frühjüdischen Traditionen in Offenbarung 4-5 unter Einschluß der Hekhalotliteratur, WUNT 2/154 (Tübingen: Mohr Siebeck, 2002). 
account for this reading, but there are no examples (as far as I have been able to ascertain) of av $\mid \varepsilon$ confusion in A02. ${ }^{38}$ The graphic and aural similarity of these words does not firmly establish this example as a scribal mistake. It is equally probable that the scribe consciously altered this word, replacing it with a word that retained morphosyntactic congruity, as well as graphic and phonological similarity with the lexeme found in his or her Vorlage. ${ }^{39}$

Such a procedure stands within the bounds of contemporary scribal behavior, and the restricted nature of transcription means that exegetical alterations usually retain some level of semblance to their Vorlage. Examples of explications of opaque narratives, linguistic difficulties, and ideological problems through intentional, yet subtle, textual adjustment are ubiquitous in Jewish and Christian antiquity. ${ }^{40}$ It is therefore possible that readings that retain some literal characteristics vis-à-vis the reading in the rest of the manuscript tradition are the conscious creations of transcribers.

An alternative explanation beyond scribal error exists in a solution toward which I have already gestured: the scribe altered this lexeme to draw it into closer lexical alliance with the tabernacle construction narrated in Exod 25:30-26:6 OG. ${ }^{41}$ If evidence exists that the alteration was designed to create further lexical parallels between Rev 11 and an external tradition, then the burden of proof falls to one who

${ }^{38} \mathrm{~B}$. Harris Cowper notes multiple vowel and diphthong substitutions in A02, but no example of au | $\varepsilon$ confusion (Codex Alexandrinus: Hē Kainē Diathēkē; Novum Testamentum Graece [London: Williams \& Norgate, 1860], x-xi). Likewise, B. F. Westcott and F. J. A. Hort proffer no evidence of au $\mid \varepsilon$ confusion (see "Notes on Orthography," in The New Testament in the Original Greek [London: Macmillan, 1885], 512-15). Natalio Fernández Marcos notes that, in the OG/LXX manuscript tradition, scribal mistakes arise from phonological similarities between letters, especially $\rho|\lambda ; \phi| \beta ; \phi|\theta ; \chi| \gamma$ (The Septuagint in Context: Introduction to the Greek Version of the Bible, trans. Wilfred G. E. Watson [Atlanta: Society of Biblical Literature, 2000], 199). Bruce M. Metzger and James R. Royse note confusion between $\alpha \mid \varepsilon$ and other similar vowel sounds $(\omega \mid 0$; ov | $\cup$; etc.), but do not catalog any examples of av $\mid \varepsilon$ confusion (see Metzger, The Text of the New Testament: Its Transmission, Corruption, and Restoration, 3rd ed. [Oxford: Oxford University Press, 1992], 190-92; and Royse, "Scribal Tendencies in the Text of the New Testament," in Ehrman and Holmes, Text of the New Testament in Contemporary Research, 462). Additionally, Royse notes $v \mid \eta$ confusion but, again, not av $\mid \varepsilon$ confusion (Scribal Habits in Early Greek, 83).

${ }^{39}$ It is possible that a female scribe produced A02, a possibility supported by a tradition that ascribes its copying to a Thecla. I retain the masculine pronoun for the scribe throughout only for the sake of convenience, making no judgment as to this person's gender. See Kim Haines-Eitzen, Guardians of Letters: Literacy, Power and the Transmitters of Early Christian Literature (Oxford: Oxford University Press, 2000), 41-52, esp. 50-52.

${ }^{40}$ See, e.g., Emanuel Tov, The Text-Critical Use of the Septuagint in Biblical Research, 2nd rev. ed., JBS 8 (Jerusalem: Simor, 1997), 100-103; Alexander Samely, Rabbinic Interpretation of Scripture in the Mishnah (Oxford: Oxford University Press, 2002), 406; Royse, Scribal Habits in Early Greek, 537-42.

${ }^{41}$ The versification system used in this discussion follows John William Wevers, Exodus, Septuaginta 2.1 (Göttingen: Vandenhoeck \& Ruprecht, 1991). 
would argue that this singular reading is a transcriptional slip. Let us now explore this possibility in detail by examining the Greek text of Exod 25:30-26:6.

The book of Revelation as a whole reuses much of the technical language from the tabernacle construction accounts in Exodus across the entirety of the composition.

\begin{tabular}{|c|c|c|}
\hline \multicolumn{3}{|c|}{ Lexical Overlap } \\
\hline Lexeme & Exod 25:31-26:5, 37:1-6 & Book of Revelation \\
\hline$\lambda u \chi v i ́ a$ & $25: 30-35$ & $1: 12-13,20 ; 2: 1,5 ; 11: 4$ \\
\hline 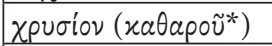 & $25: 30,{ }^{*} 35,{ }^{*} 37,{ }^{*} 38^{\star} ; 37: 4,{ }^{42} 6$ & $3: 18 ; 17: 4 ; 18: 16 ; 21: 8,{ }^{\star} 21^{\star}$ \\
\hline 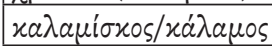 & $25: 30-35^{43}$ & $11: 1 ; 21: 15-16$ \\
\hline 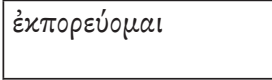 & $25: 31,32$ & $\begin{array}{l}1: 16 ; 4: 5 ; 9: 17,18 ; 11: 5 ; 16: 14 \\
19: 15 ; 22: 1\end{array}$ \\
\hline$\sigma x \eta \nu \eta \dot{\nu}$ & $\begin{array}{l}26: 1,6,7,9,12-15,17,18,22, \\
23,26,27,30,35,36 ; 37: 1,5\end{array}$ & $13: 6 ; 15: 1 ; 21: 3$ \\
\hline 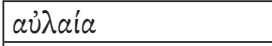 & $26: 1-6 ; 37: 1,2,10,13,14$ & $11: 4$ \\
\hline vaxiv日os & $26: 4,14$ & $21: 20(9: 17)^{44}$ \\
\hline$\pi о p \phi u ́ p a$ & $26: 1,31 ; 37: 3$ & $18: 12$ \\
\hline xoxxivos & $26: 1,31,36 ; 37: 3,23$ & $17: 3,4 ; 18: 12,16$ \\
\hline $\begin{array}{l}\pi \tilde{\eta}^{\prime} \chi \cup \varsigma \\
\mu \tilde{\eta} \chi 0 \varsigma \\
\mu \varepsilon ́ \tau \rho \circ\left(\mu \varepsilon \tau \rho \varepsilon^{\prime} \omega\right)\end{array}$ & $\begin{array}{l}25: 9,16,22 ; 26: 2,8 ; 37: 2,10 \\
25: 9,22 ; 26: 2,8,13 ; 37: 2,16 \\
26: 2,8\end{array}$ & $\begin{array}{l}21: 17 \\
21: 16 \\
21: 15,17(11: 1,2)^{45} \\
\end{array}$ \\
\hline$\beta \tilde{\sigma} \sigma \sigma o s / \beta \dot{\sigma} \sigma \sigma L v O S$ & $26: 1,31,36 ; 37: 3,7,16,21$ & $18: 12,16 ; 19: 8,14^{46}$ \\
\hline$\sigma \tau \dot{\prime} \lambda \circ s^{\prime}$ & $\begin{array}{l}26: 15-37(25 x) ; 37: 4,6,8,10 \\
12,13,15,17\end{array}$ & $3: 12 ; 10: 1$ \\
\hline$x \varepsilon \phi a \lambda i s / x \varepsilon \phi a \lambda \eta^{\prime}$ & $26: 24,32,3737: 4,6$ & $\begin{array}{l}1: 14 ; 4: 4 ; 9: 7,17,19 ; 10: 1 ; 12: 1, \\
3 ; 13: 1,3 ; 14: 14 ; 17: 3,7,9 ; \\
18: 19 ; 19: 12\end{array}$ \\
\hline$\theta v \sigma ı \alpha \tau \eta^{\prime}\llcorner\iota v$ & $20-40^{47}$ & $\begin{array}{l}\text { 6:9; 8:3, 5;9:13; 11:1; 14:18; } \\
16: 7\end{array}$ \\
\hline$\alpha \dot{u} \lambda \eta^{\prime}$ & $\begin{array}{l}27: 9,12,13,16-19 ; 37: 7 \\
13-16^{48}\end{array}$ & $11: 2$ \\
\hline
\end{tabular}

${ }^{42} \chi p \cup \sigma i o v$ is omitted in A02 in this verse.

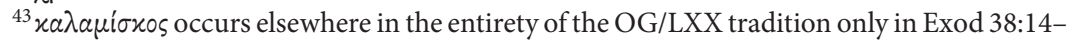
15. This lexeme is used only in the context of the branches of this lampstand. See Wevers, Notes on the Greek Text, 405-7.

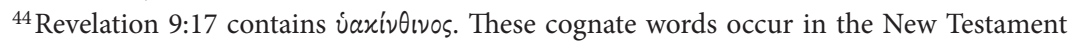
only in these two locutions in Revelation.

${ }^{45}$ See the verbal form $\mu \varepsilon \tau \rho \varepsilon ́ \omega$ in Rev $21: 15-17$ as well.

${ }^{46}$ The lexeme $\beta \tilde{\sigma} \sigma \sigma$ เvos is unique to the book of Revelation in the New Testament.

${ }^{47}$ This lexeme does not occur in Exod 25-26 or 37 but is ubiquitous elsewhere in Exod 20-40, occurring fifty-four times.

${ }^{48}$ This lexeme does not occur in Exod 25:30-26:5, 37:1-6, but is attested in other locations cataloged in the chart, as well as in Exod 38:19-21; 29:9, 20; 40:6, 33. 
This recurrent employment of identical lexemes served as the platform from which the scribe identified language in certain textual segments of the Apocalypse with the tabernacle construction instructions in OG Exodus. ${ }^{49}$ For a scribal expert with an intimate knowledge of scriptural traditions, the lexical relationship between these antecedent texts and segments of Revelation (namely, 11:1-5, 19:1-14, 21:1222:1) was not difficult to identify.

With Rev 11:1-6 in closer focus, numerous lexemes that recur in Exod 20-40 (esp. 25-27) are present:

\begin{tabular}{|c|c|c|}
\hline \multicolumn{3}{|c|}{ Lexical Overlap } \\
\hline Lexeme & Exod 25:31-26:5, 37:1-6 & Revelation 11 \\
\hline$\lambda u \chi v i \alpha$ & $25: 30-35$ & $11: 4$ \\
\hline 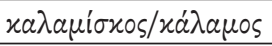 & $25: 30-35$ & $11: 1$ \\
\hline 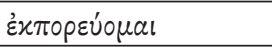 & $25: 31,32$ & $11: 5$ \\
\hline 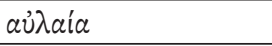 & $26: 1-6 ; 37: 1,2,10,13,14$ & $11: 4$ \\
\hline$\mu \varepsilon^{\prime} \tau \rho \circ \nu\left(\mu \varepsilon \tau \rho \varepsilon^{\prime} \omega\right)$ & $26: 2,8$ & $(11: 1,2)$ \\
\hline$\theta$ & $20-40$ & $11: 1$ \\
\hline$\alpha u ̉ \lambda \dot{y}^{\prime}$ & $\begin{array}{l}27: 9,12,13,16-19 ; 37: 7 \\
13-16\end{array}$ & $11: 2$ \\
\hline
\end{tabular}

More specifically still, the tradition underlying the description of the two witnesses

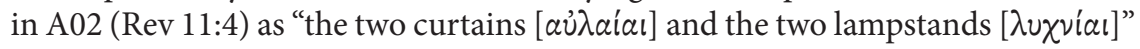
can be traced to OG Exod 25:30-26:5, where these terms occur in clusters elsewhere unparalleled in the Jewish Greek scriptural tradition. The juxtaposition of these terms is unique to OG Exod 25:30-26:5 and Rev 11:4. Forms of $\lambda u \chi v i ́ a$ occur nine times in OG Exod 25:30-38, a segment that immediately precedes Exod 26:16, where aủ $a i a$ occurs eleven times. ${ }^{50}$ This parallels the description of the two

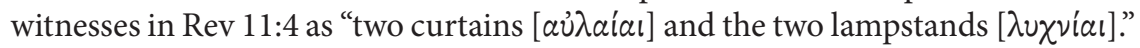

The status of a $\lambda \lambda$ ai $^{\alpha}$ as a technical term and its overwhelming occurrence in Exod 26 suggest that the scribe altered the wording of Rev 11:4 to connect the identification of the two witnesses to the tabernacle account. The absence of aủ $\lambda$ ai $\alpha$ in the New Testament and its rarity in OG/LXX suggest that its occurrence in A02 is not a phonological mistake. This textual alteration heightens the lexical consistency between Exod 25-26 and Rev 11:4, and clarifies the traditional material that

${ }^{49}$ The presence of a cluster of similar lexemes represents one of a number of textual features that activate intertextual awareness. The presence of "allusive keywords" (so Aaron Koller, Esther in Ancient Jewish Thought [Cambridge: Cambridge University Press, 2014], e.g., 174) or a quantity of shared words often signaled interpretive engagement in ancient Jewish and Christian literature. A similar criterion based on Richard Hays's work on allusion in Paul ("volume") has been plied recently in so-called Old Testament in the New Testament studies to identify the presence of allusions and echoes (see Hays, Echoes of Scripture in the Letters of Paul [New Haven: Yale University Press, 1993], 30).

${ }^{50}$ a $u^{\lambda} \lambda a^{\prime} \alpha$ also occurs three times in Exod 37:1-2 but forms of $\lambda u \chi v^{i} \alpha$ are not present. 
the scribe identified as underlying Rev 11:4. The resultant singular reading is the residual evidence of the scribe's attentiveness to and knowledge of external scriptural traditions activated in the process of copying. The act of transcription was not passive but was undertaken in connection with the scribe's past scriptural engagements. ${ }^{51}$ This change, which may have been premeditated (i.e., planned before transcription), was created based on the scribe's knowledge of the scriptural tradition, learned in part through past experience of copying. The lexical clusters within Revelation that correspond to Exod 25-26 OG factored into this example of lexical substitution.

This singular reading was a shrewd procedure that allowed the scribe to remain faithful to his Vorlage in terms of syntax and phonology, while simultaneously altering the lexical value of his Vorlage to cause Rev 11:4 to cohere more closely with a perceived allusion. The scribe intuited an allusion and altered the wording of Revelation to conform to this intuition, perhaps creating an allusion where one did not clearly exist. ${ }^{52}$ This alteration, based in part upon the scribe's awareness of Exod 25-26, is, to borrow a phrase from Karel van der Toorn, a vigorous "display of scribal dexterity." 53

\section{Revelation 14:9}

An additional example of a reading that was created due to the awareness of external scriptural traditions is found in Apoc. A02 14:9.

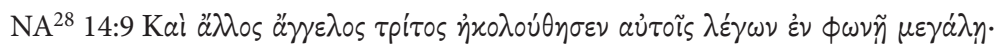

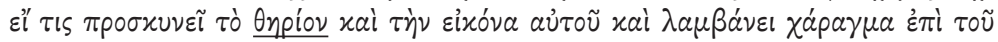

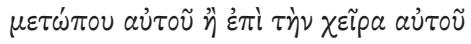

And another angel, a third, followed them saying in a loud voice: "if anyone worships the beast and his image and receives a stamp on his forehead or his hand ..."

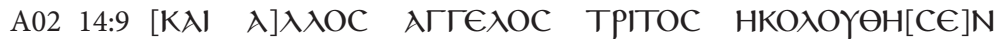

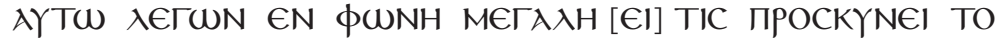 OYCIACTHPION [K]AI THN EIKONA AYTOY KAI AAMBANEI [X] АРАГМА ЄПI TOY METWПOY AYTOY H EПI [T]HN XEIPA AYTOY}

${ }^{51}$ See Klaus Junack, "Abschreibpraktiken und Schreibergewohnheiten in ihrer Auswirkung auf die Textüberlieferung," in New Testament Textual Criticism: Its Significance for Exegesis; Essays in Honour of Bruce M. Metzger, ed. Eldon Jay Epp and Gordon D. Fee (Oxford: Clarendon, 1981), 277-95.

${ }^{52}$ See also Karrer, "Der Text der Johannesoffenbarung," 388, who argues that this reading must be considered when constructing the main text of the Editio Critica Maior of Revelation based on transcriptional probability, even though singular readings are usually considered to be secondary intrusions into the tradition.

${ }^{53}$ Karel van der Toorn, Scribal Culture and the Making of the Hebrew Bible (Cambridge: Harvard University Press, 2007), 40. 
And another angel, a third, followed him saying in a loud voice: "if anyone worships the altar and its image and receives a stamp on his forehead or on his hand ..."

Numerous explanations for this singular reading have been proffered. David Aune argues that the scribe understood Onpiov as an abbreviation of $\theta v \sigma \iota \alpha \sigma \eta^{\prime} \rho{ }^{\circ},{ }^{54}$ but there are no examples of this abbreviation in the manuscript evidence. ${ }^{55}$ Hernández categorizes this reading as an insignificant singular that is "nonsense in context" in its immediate literary context this reading complicates the sense of the locution and is not explicable on internal grounds. ${ }^{56}$ These observations do not, however, necessarily make this reading insignificant.

Again, like the previous example, the reading is graphically and phonologically similar ( $\underline{\mathrm{OH} P I O N}$ | $\underline{\mathrm{O}}$ YCIACT $\underline{\mathrm{HPION}})$ to the reading preserved in the rest of the manuscript tradition, and it is difficult to deduce a procedure by which the scribe altered this reading based on internal evidence. This reading becomes more difficult to explain when the preeminence of the lexeme Onpiov in the texts immediately preceding and following Rev 14:9 is noted. ${ }^{57}$ Attributing this reading to a transcriptional error is an unlikely answer, since the alteration remains grammatically cohesive and there are no clear local textual features that would trigger this expansion. The lexical substitution does not seem to reflect care for the internal discourse of the pericope.

I suggest that a yet unexplored solution may lie in an external textual harmonization to $2 \mathrm{Chr} 32: 12 \mathrm{OG}$.

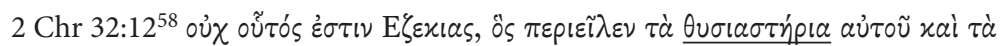

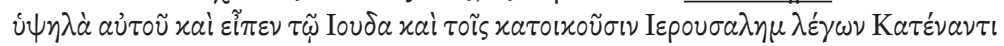

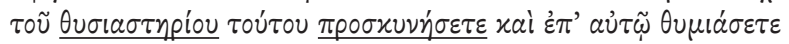

Is this not Hezekiah who took away his altars and his high places and he said to Judah and to those dwelling in Jerusalem saying: "worship before this altar and on it make an incense offering."

Like the previous example, 2 Chr 32 OG evidences significant lexical overlap with the book of Revelation.

${ }^{54}$ David Aune, Revelation 6-16, WBC 52b (Nashville: Nelson, 1998), 787.

${ }^{55}$ Hernández, Scribal Habits and Theological Influences, 106 n. 45.

${ }^{56}$ Ibid., 105-6. Weiss suggests that this reading is a "reine Schreibfehler" (Die JohannesApokalypse, 60).

${ }^{57}$ See $11: 7 ; 13: 1-4,11,12,14,15,17,18 ; 14: 11 ; 15: 2 ; 16: 2,10,13 ; 17: 3,7,8,11-13,16,17$; $19: 19,20 ; 20: 4,10$.

${ }^{58}$ The Greek text of 2 Chronicles is taken from Alan England Brooke, Norman McLean, and H. St. John Thackeray, The Old Testament in Greek according to the Text of Codex Vaticanus, 3 vols. in 9 (Cambridge: Cambridge University Press, 1932), vol. 2.3. I have changed the text in this edition where A02 is in disagreement with B, most notably the inclusion of oủ $x$. 


\begin{tabular}{|c|c|c|}
\hline \multicolumn{3}{|c|}{ Lexical Overlap } \\
\hline Lexemes & 2 Chronicles & Revelation \\
\hline 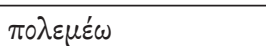 & $32: 2$ & $2: 16,12: 7,13: 4,17: 14,19: 11$ \\
\hline$\pi \rho \varepsilon \sigma \beta u ́ \tau \varepsilon \rho \circ \varsigma$ & $32: 3,31$ & $\begin{array}{l}4: 4 ; 10 ; 5: 5,6,8,11,14 ; 7: 11,13 ; \\
11: 16 ; 14: 3 ; 19: 4\end{array}$ \\
\hline$u ́ \delta \omega \rho+\pi \eta \gamma \eta \dot{~}$ & $32: 3,4$ & $7: 17,8: 10,14: 7,16: 4,21: 6$ \\
\hline$\varepsilon^{\prime \prime} \xi \omega(\theta \varepsilon \nu) \tau \tilde{\eta} \varsigma \pi \lambda^{\prime} \varepsilon \omega \varsigma$ & $32: 3$ & $14: 20$ \\
\hline$\pi \circ \tau \alpha \mu o ́ s$ & $32: 4$ & $\begin{array}{l}8: 10 ; 9: 14 ; 12: 15,16 ; 16: 4,12 \\
22: 1,2\end{array}$ \\
\hline$\ddot{\delta} \omega \omega \rho+\pi 0 \lambda u^{\prime} \varsigma$ & $32: 4$ & $1: 15,14: 2,17: 1,19: 6$ \\
\hline$\tau \varepsilon \tilde{\chi} \chi \circ \varsigma$ & $32: 5,18$ & $21: 12,14,15,17-19$ \\
\hline 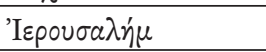 & $32: 2,9,10,12,18,19,33$ & $8: 12 ; 21: 2,10$ \\
\hline$\theta v \sigma ı \sigma \tau \eta ́ p ı \nu$ & $32: 12$ & $6: 9,8: 3,14: 9(\mathrm{~A} 02)$ \\
\hline 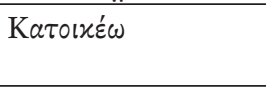 & $32: 12$ & $\begin{array}{l}2: 13 ; 3: 10 ; 6: 10 ; 8: 13 ; 11: 10 ; 13: 8, \\
12,14 ; 17: 2,8\end{array}$ \\
\hline 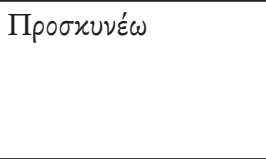 & $32: 12$ & $\begin{array}{l}3: 9 ; 4: 10 ; 5: 14 ; 7: 11 ; 9: 20 ; 11: 1 \\
16 ; 13: 4,8,12,15 ; 14: 7,9,11 \\
15: 4 ; 16: 2 ; 19: 4 ; 10,20 ; 20: 4 \\
22: 8,9\end{array}$ \\
\hline$\theta \nu \mu \dot{\alpha}^{\prime} \omega / \theta \nu \mu i \alpha \mu \alpha$ & $32: 12$ & $5: 8 ; 8: 3,4 ; 18: 13$ \\
\hline 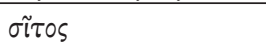 & $32: 28$ & $6: 6,18: 13$ \\
\hline oี้ของ & $32: 28$ & $\begin{array}{l}6: 6 ; 14: 8,10 ; 16: 19 ; 17: 2 ; 18: 3, \\
13 ; 19: 15\end{array}$ \\
\hline $\mathrm{B} \alpha \beta u \lambda \omega^{\prime} \nu$ & $32: 31$ & $14: 8 ; 16: 19 ; 17: 5 ; 18: 2,10,21$ \\
\hline
\end{tabular}

The lexical overlap specifically between $2 \mathrm{Chr} 32$ and Rev 14 is also impressive.

\begin{tabular}{|c|c|c|}
\hline \multicolumn{3}{|c|}{ Lexical Overlap } \\
\hline Lexemes & 2 Chronicles & Revelation 14 \\
\hline$\pi \rho \varepsilon \sigma \beta u ́ \tau \varepsilon \rho о \varsigma$ & $32: 3,31$ & $14: 3$ \\
\hline$\ddot{\delta} \delta \omega \rho+\pi \eta \gamma \eta$ & $32: 3,4$ & $14: 7$ \\
\hline$\varepsilon^{\prime \prime} \xi \omega(\theta \varepsilon \nu) \tau \tilde{\eta} \varsigma \pi \delta^{\prime} \lambda \varepsilon \omega \varsigma$ & $32: 3$ & $14: 20$ \\
\hline$\ddot{v} \delta \omega \rho+\pi 0 \lambda u ́ s$ & $32: 4$ & $14: 2$ \\
\hline 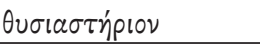 & $32: 12$ & 14:9 (A02) \\
\hline 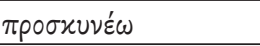 & $32: 12$ & $14: 7,9,11$ \\
\hline oก̃vos & $32: 28$ & $14: 8$ \\
\hline $\mathrm{B} \alpha \beta u \lambda \omega^{\prime} \nu$ & $32: 31$ & $14: 8$ \\
\hline
\end{tabular}


More important still, in 2 Chr 32:12, the translator of OG Chronicles twice placed forms of the lexeme $\theta u \sigma ı \sigma \tau \eta \dot{p} ı v$ in the mouth of Sennacherib: once as part of a prepositional phrase serving as the indirect object of the imperative $\pi \rho \circ \sigma \varkappa \cup \nu \eta \dot{\sigma} \varepsilon \tau \varepsilon$ ("worship"). A similar, although inexact, collocation of verb and object occurs in Apoc. A02 14:9: ПPOCKYNEI TO OYCIACTHPION ("worship the altar"). In the remainder of the OG/LXX tradition outside of $2 \mathrm{Chr} 32: 12 \pi \rho \circ \sigma x \cup \nu \varepsilon$ e $\omega$ and

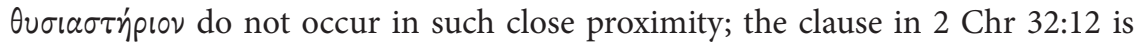
unique in this regard. Again, the exclusive occurrence of these words in a clause and the larger lexical points of connection between 2 Chr 32 and Rev 14 suggest that the scribe altered Rev 14:9 to correspond more closely to $2 \mathrm{Chr} 32: 12$ and its surrounding co-texts. The scribe substituted the lexeme attested in all other copies for one that was graphically and phonologically similar, yet retained a different semantic sense.

This alteration creates greater linguistic correspondence between $2 \mathrm{Chr} 32$ and Rev 14, a move that alerts text users to the antecedent material. The singular reading is the residual evidence of the scribe's perception of a relationship between the Sennacherib story of $2 \mathrm{Chr} 32$ and the narrative of Rev 14, clarifying his perception of an allusion in Rev 14:9.

This singular reading highlights an analogy between Sennacherib in 2 Chr 32 and the beasts described in Rev 13-14. Beyond lexical overlap, these accounts share numerous plot features:

\begin{tabular}{|l|l|}
\hline \multicolumn{2}{|c|}{ 2 Chrot Alignment } \\
\hline \multicolumn{1}{|c|}{ 2 } & \multicolumn{1}{c|}{ Revelation } \\
\hline Sennacherib attacks Judah (32:1) & Beast makes war with God's people (13:7) \\
\hline $\begin{array}{l}\text { Hezekiah's assertion of military dominance } \\
(32: 7)\end{array}$ & Appearance of the Lamb's army (14:1-5) \\
\hline Appeal to God for protection (32:8) & Call for endurance and worship (14:7; 12) \\
\hline $\begin{array}{l}\text { Blaspheming of God by Assyrians (31:9- } \\
\text { 19) }\end{array}$ & Beast blasphemes God (13:5-6) \\
\hline $\begin{array}{l}\text { Angelic deliverance of Jerusalem; judgment } \\
\text { of the Assyrians (32:20-23) }\end{array}$ & $\begin{array}{l}\text { Angelic judgment scene (14:14-20); beasts } \\
\text { judged (19:20) }\end{array}$ \\
\hline
\end{tabular}

Although the plot elements do not align chronologically within both narratives, the presence of these features suggests a connection. This correlation of elements is similar to typological elements identified by Michael Fishbane in the Hebrew Bible, particularly "typologies of a historical nature," in which historical events function as prototypes for present or future events. ${ }^{59}$ It seems that the scribe read

${ }^{59}$ Michael Fishbane, Biblical Interpretation in Ancient Israel (Oxford: Oxford University Press, 1985), 358-68. The solidification of this typology by lexical change in this example draws an interesting parallel between scribal habits in early Christian manuscripts and interpretive elements native to the Hebrew Bible and Second Temple Jewish literature. 
Revelation with a similar interpretive mind-set, which strengthens the typological relationship between $2 \mathrm{Chr} 32$ and Rev 13-14 based on already extant lexical overlap/borrowing and parallel plot features in order to provide another point of contact between narratives. In each account, the enemies are menacing and powerful, yet victory is assured through faithfulness to God. The accounts ultimately conclude with the defeat of these frightening foes by divine judgment. For a reader of Revelation in A02 who is conscious of the story of the defeat of the Assyrian army in $2 \mathrm{Chr} 32$, the defeat of the beasts in Rev 13 is assured at the outset. The singular reading in Rev 14:9 not only elucidates a potential allusion to Rev 13-14 but also provides the reader with an intrinsic approach to reading this text in conversation with the $2 \mathrm{Chr} 32$.

The skill of the scribe's intervention in the text of Revelation is manifest. This lexical alteration was made within the graphic and phonological confines of the remainder of the tradition - the altered lexeme retains each grapheme of the lexeme in the scribe's Vorlage in identical order, with an additional six graphemes inserted into the middle of the word. An identical mechanic is operative in the alteration of ipıs to IEPEIC in Apoc. A02 4:3 (cf. $N$ 2329). The phonetic value of the source lexeme (Anpiov) and the singular reading ( $\Theta Y C I A C T H P I O N)$ retain an identical consonance. The scribe explicated a traditional source that was in some sense already implied in the wording of the Apocalypse.

\section{Exegetical Reasoning and Second Temple JEWISH LITERATURE}

The conclusion that both of these readings are the result of the scribe's awareness of antecedent scriptural wording stands in contrast to the prevailing position in New Testament textual studies. Scholars tend to explain the majority of textual variation as either the result of (premeditated) theological reasoning or in scribendo transcriptional error. Karrer, for example, suggests that the readings in Apoc. A02 11:4 and 14:9 are explicable on ideological grounds (type 4 ) ${ }^{60}$ The primary thrust of Karrer's article-that the Greek text of Revelation is in serious need of a critical reevaluation, and that the nexus of theology, textual criticism, and textual history is a burgeoning area of inquiry-is both perceptive and important. ${ }^{61} \mathrm{He}$ also accurately observes the existence of an interesting pattern, in which these textual alterations in A02 create more cultic imagery. Lacking in Karrer's argument, however, is attentiveness to the external traditions that influence some of the textual

${ }^{60}$ Karrer, "Der Text der Johannesoffenbarung," 383-88. He also holds open the possibility that the reading in 11:4 may have a claim for originality (type 1).

${ }^{61}$ See also Martin Karrer, "The Angels of the Congregations in Revelation-Textual History and Interpretation," Journal of Early Christian History 1 (2011): 64-66. 
anomalies in Apoc. A02; his argument therefore disregards the possibility that exegetical reasoning gave rise to these readings. Ideology and awareness of external textual traditions need not be mutually exclusive categories, and it is impossible to divorce theology from ancient scriptural reading. But the evidence in the preceding examples suggests that the variation in Rev 11:4 and 14:9 in A02 is primarily the result of exegetical reasoning perhaps deployed to particular theological ends.

It is at this juncture that the study of the transmission of the Hebrew Bible in the late Second Temple period can provide assistance in understanding the shape of textual variation in the New Testament. It is well documented that perceived connections between scriptural texts were a primary factor leading to changes and development in the wording of writings in the Hebrew Bible, however minute the intuited connection may have been. ${ }^{62}$ The influence of external traditions on the text of a particular work was authorized by various textual hermeneutics, including the "awareness of an interrelated, sacred scriptural whole." ${ }^{3}$ This awareness is operative in the fifth century, especially when the scriptural whole is codified in a single physical entity like A02. This presupposition of Scripture as a collection of sacred works, an attitude largely absent in the praxis of modern text-critical endeavors, demands that scholars also consider textual variation as the remnants of ancient exegetical encounters. Singular readings or other textual anomalies should be considered beyond their value in establishing a hypothetical Ausgangstext. Scholars should emphasize any potential external scriptural traditions that might have influenced the shape of strangely worded texts, especially when the text contains explicit or implicit references to other scriptural works. Studies on the reuse and transmission of Scripture in the late Second Temple period, including engagement with the scrolls from the Judean Desert, have the potential to provide New Testament scholars with helpful avenues of inquiry in this regard. ${ }^{64}$ It is not that scholars have failed to consider exegetical reasoning altogether, but that this explanation for textual change has been downplayed in favor of emphasizing

\footnotetext{
${ }^{62}$ The most recent and comprehensive study of this issue is located in Teeter, Scribal Laws, $7-174$.

${ }^{63}$ Ibid., 204; see also Eugene Ulrich, The Dead Sea Scrolls and the Origins of the Bible, SDSSRL (Grand Rapids: Eerdmans, 1999), 79-98.

${ }^{64}$ From the many studies that explore Second Temple Jewish texts, I will point to only a representative sample, including Teeter, Scribal Laws (2014); William A. Tooman, Gog of Magog: Reuse of Scripture and Compositional Technique in Ezekiel 38-39, FAT 2/52 (Tübingen: Mohr Siebeck, 2011); Molly M. Zahn, Rethinking Rewritten Scripture: Composition and Exegesis in the 4QRewroked Pentateuch Manuscripts, STDJ 95 (Leiden: Brill, 2011), http://dx.doi.org/10.1163/ ej.9789004193901.i-282; Henze, Biblical Interpretation at Qumran (2005); Henze, ed., A Companion to Biblical Interpretation in Early Judaism (Grand Rapids: Eerdmans, 2012); Martin Jan Mulder, ed., Mikra: Text, Translation, Reading and Interpretation of the Hebrew Bible in Ancient Judaism and Early Christianity, CRINT, Section 2, Literature of the Jewish People in the Period of the Second Temple and the Talmud 1 (Assen: Van Gorcum, 1988).
} 
transcriptional issues or theological scruples. Exegetical reasoning is intricately connected to these other factors, but a distinct phase in the process.

\section{Conclusions}

The preceding discussion leads to the following conclusions. First, there is a diverse range of motivating factors that created singular readings in the textual history of the New Testament, factors that illuminate aspects of textual production, the social realities of scribalism, and the reception of New Testament works in late antiquity. Transcription errors and assimilation to internal grammatical or discourse conventions are assuredly the most prevalent explanations for singular readings. Additionally, changes based on theological perceptions also exist in the manuscript record. Yet another motivation-assimilation to external traditions based on awareness of lexical and thematic relationships-provides a further scribal proclivity that gives rise to exegetical textual variation (sometimes in the form of singular readings) in particular manuscripts. This variation is not unbridled or whimsical but is controlled by the scribe's understanding of the copied text, namely, the influence of allusions that underlie particular locutions in Revelation. ${ }^{65}$ In this way, the alterations introduced into the tradition, although not precise representations of the wording of an antegraph, are faithful to the text insofar as they represent the scribe's understanding of the text's meaning-the scribe is faithful to his own perceived interpretation of the text, not necessarily always to its wording. This reality is not specific to A02 for the Apocalypse. The text of Revelation in Codex Sinaiticus ( $(\boldsymbol{\aleph})$ contains numerous and egregious scribal errors alongside a number of readings that seem to preserve an interest in theological nuance and awareness of external tradition. ${ }^{66}$ Awareness of antecedent traditions in this manuscript is even more obvious than in A02. Regardless of which exemplar one examines, the typology of singular readings presented above provides a critical tool for evaluating these readings and their causes within the textual history of the New Testament generally, and in the Apocalypse specifically.

Second, the scribe was aware of antecedent Greek scriptural traditions and the subtle textual details therein. The examples explored above were created in response to lexical overlap with texts in the OG/LXX and the alignment of typological features. Numerous textual and linguistic cues coalesced to suggest that Exod 25-26 and 2 Chr 36 stood behind Rev 11:4 and 14:9 respectively. ${ }^{67}$ Multiple conflicting

${ }^{65}$ See Haines-Eitzen, Guardians of Letters, 105-27.

${ }^{66}$ See Juan Hernández Jr., "Codex Sinaiticus: An Early Christian Commentary on the Apocalypse?", in Codex Sinaiticus: New Perspectives on the Ancient Biblical Manuscript, ed. Scot McKendrick et al. (London: British Library, 2015), 107-26.

${ }^{67}$ In regard to the association of Exod 25 with Rev 11:4, Beale also makes this connection, mentioning Exod 25:30-31 (Book of Revelation, 576). 
tendencies are present in these textual alterations: a conservative desire to remain faithful to the wording of the Vorlage and an impulse to explicate the presence and identity of the traditional sources alluded to in the book of Revelation. On the one hand, these readings retain literal relationships to their sources graphically, phonologically, and, in the case of Rev 14:9, in its serial presentation of graphemes. On the other hand, the scribe's copy is not precisely literal to its Vorlage in terms of lexical items. The lexical alterations retain some formal resemblance to the Vorlage, while altering the semantics of the phrase. That these alterations may result in unintuitive turns of phrase (e.g., "worship the altar") suggest that the scribe was constrained by the norms of acceptable textual intrusion and the type of alteration allowable by his form of transmission. A full appraisal of variant readings in Apoc. A02 is required to determine the extent and form of socially acceptable textual reworking in this period. ${ }^{68}$

Finally, the features of these alterations intimate parallels between the scribal handling of New Testament documents and earlier examples of the interpretation and transmission of the Hebrew Bible in the Second Temple period. A helpful avenue for New Testament textual scholars to describe exegetical textual variation in the Greek manuscripts is the study of textual variation in the Hebrew Bible in the late Second Temple period. Observations from this field raise interesting comparative questions regarding the relationship between the production of copies and transmission of the works within these corpora and the shared facets of an ancient scribal tradition. The modes of transmission witnessed in Apoc. A02 and Second Temple literature both preserve facilitating tendencies within textual cultures that tend, to differing degrees, to privilege the precise replication of wording. ${ }^{69}$ Michael Segal's observation pertaining to "Rewritten Bible" compositions also holds true, to some degree, for the scribe of our text: "the active intervention of scribes in these texts was accepted in this period and was not viewed as an affront to the sanctity of the text." ${ }^{70}$ The socially permitted level of textual interference is admittedly minimized by the fifth century CE, but the scribe retained a limited freedom to alter the wording of copies in quantitatively small ways. For the most part, this occurs

\footnotetext{
${ }^{68}$ Some significant work has been done in this area in regard to different early manuscripts, but more is needed. See Royse, Scribal Habits. Hernández (Scribal Habits and Theological Influences) also makes a profitable step in this direction, and his work is a helpful tool in accessing data pertaining to singular readings in the early codices that preserve Revelation.

${ }^{69}$ See especially Teeter, who suggests that two concurrent models of scriptural transmission existed in this period: one devoted to improving the readability of the tradition, and another that privileged the precise replication of wording (Scribal Laws, 208-10). This second model is the prevailing mode of transmission of New Testament manuscripts, but features of facilitation exist within this model.

${ }^{70}$ Michael Segal, "Between Bible and Rewritten Bible," in Henze, Biblical Interpretation at Qumran, 16. The boundaries of acceptable intervention in early New Testament documents are what require further exploration.
} 
at the lexical level, although some omissions of multiple words are also present. ${ }^{71}$ Recourse to information about the habits of scribes from the Second Temple period ought to be considered with caution, since the scribe and these tradents stand on very different chronological, ideological, and social planes; however, this endeavor may provide solutions to textual anomalies in the New Testament manuscript record. In my view, the scribe is not merely a copyist, and scribal operationsrather than simply being limited to acts of transcription-reflect also acts of interpretation and explication. Because of this, it is not always possible to distinguish between scribe and exegete, just as it is not always possible to contrive the boundary between textual and reception history. ${ }^{72}$

${ }^{71}$ See Apoc. A02 7:1b, 4; 8:10.

${ }^{72} \mathrm{See}$ also the problematizing of the boundary between biblical criticism and reception history in Brennan W. Breed, Nomadic Text: A Theory of Biblical Reception History, ISBL (Bloomington: Indiana University Press, 2014), esp. 1-14. 